\title{
Fossil bear material from the oldest deposits in the Jasna Strzegowska cave (Silesia, southern Poland)
}

\author{
Adrian MARCISZAK ${ }^{1, *}$ and Grzegorz LIPECKI ${ }^{2}$ \\ 1 University of Wrocław, Faculty of Biological Sciences, Institute of Environmental Biology, Department of Palaeozoology, \\ Sienkiewicza 21, 50-335 Wrocław, Poland \\ 2 Polish Academy of Sciences, Institute of Systematics and Evolution of Animals, Sławkowska 17, 31-016 Kraków, Poland
}

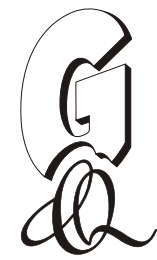

\begin{abstract}
Marciszak, A., Lipecki, G., 2020. Fossil bear material from the oldest deposits in the Jasna Strzegowska cave (Silesia, southern Poland). Geological Quarterly, 64 (4): 861-875, doi: 10.7306/gq.1556
\end{abstract}

Associate Editor: Michał Zatoń

Fossil bear material from the lowermost deposits of the Jasna Strzegowska cave is described and its taxonomic status assessed. Comparison with bear remains from other Early and early Middle Pleistocene localities of Eurasia shows the presence of two bear species: Ursus etruscus and $U$. deningeri, based on morphological and size characters of the teeth and postcranial bones. The teeth of $U$. deningeri from the Jasna Strzegowska cave are larger, wider and have much more complicated occlusal surfaces when compared with the teeth of $U$. etruscus. Both bear species are characterized by relatively short and robust metapodials, although those of $U$. etruscus are on average less massive. Some differences in muscle attachments and articular surfaces have also been found. Metapodials of primitive arctoid bears, that co-occurred with $U$. etruscus and $U$. deningeri, are much longer and slimmer. U. etruscus and $U$. deningeri probably did not live in the Jasna Strzegowska cave at the same time. Based on its time range in Eurasia and morphological characteristics, the age of $U$. etruscus is estimated as Early Pleistocene, between 1.8-1.3 Ma. This is its first description from Poland, and the remains described are in size and morphology indistinguishable from material from other European localities. For U. deningeri, an early Middle Pleistocene age is suggested.

Key words: teeth, metapodials, morphotypes, evolution, lineage.

\section{INTRODUCTION}

The evolutionary history of bears of the genus Ursus is a traditional topic of palaeontological studies (e.g., von Reichenau, 1904, 1906; Freudenberg, 1914; Rode, 1931, 1935) because of the presence of abundant and well-preserved material. The main interest focuses on the Late Pleistocene, while there are many papers too dealing with Middle Pleistocene forms (e.g., Kurtén, 1956, 1959; Musil, 1972, 1995; Argant, 1991; Bishop, 1982; Torres, 1988; Tchernov and Tsoukala, 1997; Baryshnikov and Foronova, 2001; Baryshnikov and Kalmykov, 2005; Sher et al., 2011).

While the evolutionary history of bears of the Ursinae from the mid Middle Pleistocene to the Holocene (the last $600 \mathrm{ky}$ ) is well-documented, especially for the deningeroid-spelaeoid lineage, current re-evaluation of this process is complicated due to the absence of reliable data from the crucial period of the

\footnotetext{
* Corresponding author, e-mail: adrian.marciszak@uwr.edu.pl
}

Received: April 22, 2020; accepted: July 7, 2020; first published online: September 16, 2020 early Middle Pleistocene (900-700 ka). So far, only few studies have been published (e.g., Kurtén, 1969; Musil, 1974; Wiszniowska, 1989), while important new data on late Early Pleistocene ursids close to arctoid and spelaeoid bears have appeared (Moullé, 1992; García and Arsuaga, 2001; Musil, 2001; García, 2003; Madurell-Malapeira et al., 2009; Rabeder et al., 2010). These new discoveries have demanded a radical re-evaluation of traditional models on the evolution of Ursinae bears, refining the diagnostic characters, variation patterns and phylogenetic significance, including establishing reliable autapomorphic characters discriminating the arctoid and spelaeoid lineages (Wagner and Čermák, 2012). Due to the lack of detailed information, several individual specimens were described as new taxa of uncertain affinity (e.g., García and Arsuaga, 2001; Musil, 2001). Among this overwhelming crowd of different conceptions, two papers have served as especially valuable viewpoints (Rabeder et al., 2010; Wagner and Čermák, 2012).

In such situation, any new material allowing resolution of this problem is especially valuable, even if the remains are not very numerous. As a consequence, and especially in the case of Ursinae bears, the stratigraphic determination of a number of localities has long been controversial. With respect to these localities, where possible, the best way to corroborate the previously published dates is to provide a new detailed taxonomic 
re-evaluation of the available fossil record. The precise stratigraphic position of faunal assemblages is of great importance for the correct interpretation of migration events and evolution of particular taxa/lineages in Europe during the Pleistocene (Wagner et al., 2017).

One such locality is the Jasna Strzegowska cave, long known. Excavations of this cave provided abundant material of birds and mammals (Sawicki, 1949, 1953; Mirosław-Grabowska and Cyrek, 2009; Stefaniak et al., 2009; Nadachowski et al., 2016; Ratajczak et al., 2016). However, most of the bone remains have never been studied in detail, and so far only birds and herbivores have been described (Bocheński et al., 2012; Stefaniak, 2015; Nadachowski et al., 2016; Ratajczak et al., 2016). For this reason, the faunal list is fairly incomplete and should be treated as preliminary. Among carnivores, only the presence of Ursus sp. and Ursus spelaeus has been mentioned, but without detailed description (Stefaniak et al., 2009). The present paper provides a detailed description of the bear material from the oldest deposits of the Jasna Strzegowska cave together with a discussion of taxonomic and stratigraphic issues.

\section{SITE}

Jasna Strzegowska cave (50²4'54" N 1941'32" E, $430 \mathrm{~m}$ a.s.l., no. 394 in Kowalski, 1951 and no. IV.D.2 in Szelerewicz and Górny, 1986), also known as Jasna cave or Jasna w Strzegowej cave, is situated in the Jamy rock near the Strzegowa-Kolonia (Okupniki) village (commune Wolbrom, Olkusz county, Małopolska Voivodeship; Fig. 1). Historically, the rock is described as "Jamy" and is situated in the Smoleńsko-Niegowonickie range of the Polish Jura, the easternmost part of Silesia. The cave was formed in an isolated limestone hill, and filled with deposits $>2 \mathrm{~m}$ thick. With a total length of $85 \mathrm{~m}$, the cave includes two chambers and a small corridor, and the main entrance is north-facing. The chamber, $\sim 100 \mathrm{~m}^{2}$ and $8 \mathrm{~m}$ high, is the largest preserved cave chamber in the middle part of the Polish Jura (Stefaniak et al., 2009).

This locality has long been known and was first mentioned by Przesmycki (1912). In 1947-49, excavations at the entrance

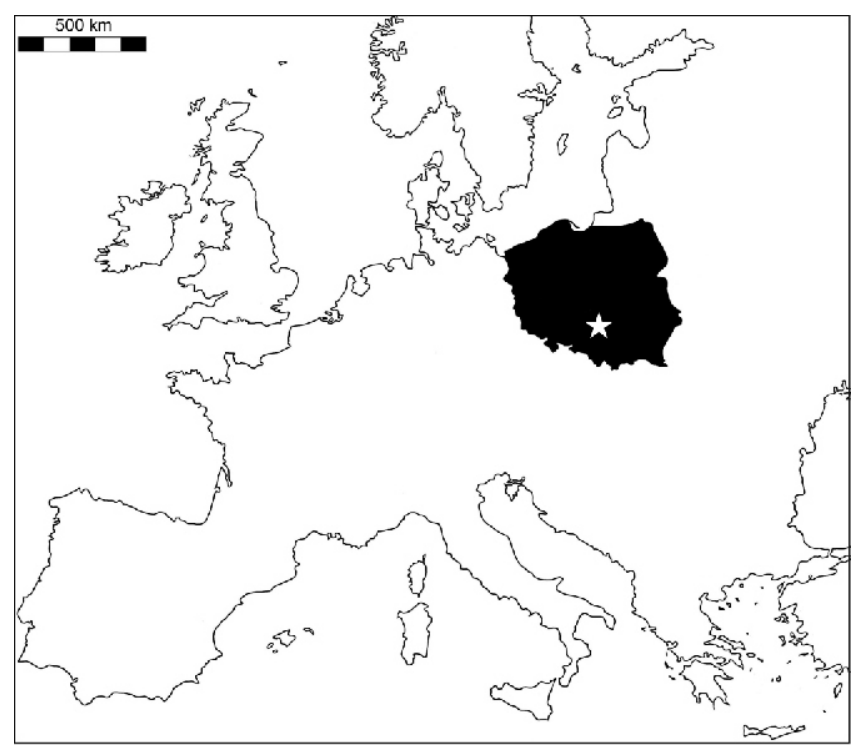

Fig. 1. Location of the Jasna Strzegowska cave (indicated by star) in Europe and in the main chamber were conducted by L. Sawicki. During this exploration, the deposits were completely removed. In a short lithological description, based on field studies, the following layers were distinguished: layer 1 - rocky limestone; layer 2 - grey clay with detritus; layer 3 - detritus loam; layer 4 - soil with dark grey loam; layer 5 - medium-grained, yellow-brown sands containing bones and flint artefacts; layer 6 - typical light loess; layer $6 \mathrm{a}$ - darker loess with scattered limestone fragments; layer 7 - Neolithic layer, old deposit surface; layer 7a loess burnt in the bottom of a Neolithic hearth; layer 8 - talus. In addition to faunal remains, a few flint artefacts were also found (Sawicki, 1953).

In 1991-1994, K. Cyrek carried out excavations in a corridor called Lisie Jamy, not excavated by L. Sawicki (Rybicka and Cyrek, 1997). In the $2 \mathrm{~m}$ deep profile, six layers were distinguished: layer 1 - red erosion loam; layer 2 - rounded and chemically eroded rubble; layer 3 - amorphous loess with sand lenses and a single rubble layer; layer 4 - sandy loam with diverse rubble; layer 5 - loess with admixture of sand and sharp-edged rubble; layer 6 - sandy-loess Holocene humus. The deposits included hiatuses, with the oldest layer 2 dating back to MIS 6, layer 3 to MIS 5e, layer 6 to MIS 2, and layer 7 to MIS 1 (Mirosław-Grabowska and Cyrek, 2009). A production settlement with flint hatchets was discovered above the cave, at the top of the rock. The excavations provided, in addition to animal remains, numerous flint artefacts representing four Palaeolithic (Aurignacian, Mousterian, Acheulian and Gravettian) and one Neolithic (Lengyel culture) level (Sawicki, 1949, 1953; Mirosław-Grabowska and Cyrek, 2009; Stefaniak et al., 2009).

\section{MATERIAL AND METHODS}

Measurements of the fossils were taken point to point, with an electronic calliper, to the nearest $0.1 \mathrm{~mm}$. Each value is the mean of three measurements. A standard scheme for measurements was applied and modified from Hilpert (2006) and Argant (2010) and is shown in Figure 2. Osteological and dental terminology follows Baryshnikov (2007) and the standard scheme for teeth measurements was applied and modified from Baryshnikov (2007) and shown on Figure 2.

The definition and subdivisions of the Quaternary follow Gibbard and Cohen (2008) and Gibbard and Head (2009a, b). The definition and subdivisions of mammal zones and their correlation with the chronostratigraphic scale as well as with MN-zones follow Kahlke et al. (2011). The nomenclatural codification follows the 4th edition of the International Code of Zoological Nomenclature (ICZN, 1999). Capital and lowercase letters, C/c (canines), l/i (incisors), P/p (premolars), and M/m (molars), refer to upper and lower teeth, respectively.

The bones of Pleistocene bears from the following sites were used as comparative material:

1. Ursus etruscus: Dmanisi (Medin et al., 2019); Fuente Nueva 3 (Medin et al., 2017); Monte Argentario (Petrucci and Sardella, 2009); Olivola (Mazza and Rustioni, 1992); Pietrafitta (Mazza and Rustioni, 1992); Pirro Nord (Petrucci et al., 2013); Saint Vallier and Senéze (Mazza and Rustioni, 1992; Argant, 2004); Trlica (Vislobokova and Agadjanian, 2015); Tsiotra Vryssi (Koufos et al., 2018); Valdarno (different sites, Mazza and Rustioni, 1992); Venta Micena (Medin et al., 2017).

2. Ursus ex gr. arctos (sensu Rabeder et al., 2010): Deutsch Altenburg (Rabeder et al., 2010); Południowa cave; Sackdilling cave; Trinchera Dolina 4 (Garcia and 


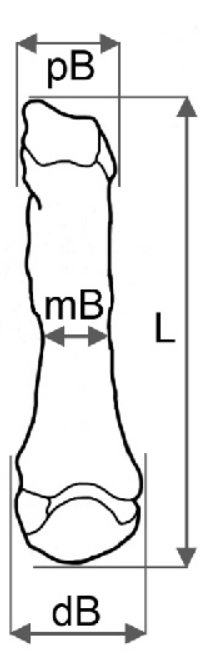

$\mathrm{mc} 2$

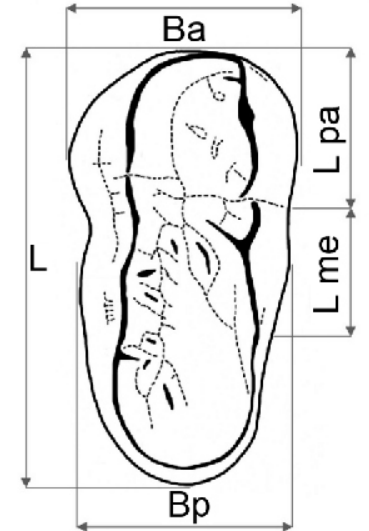

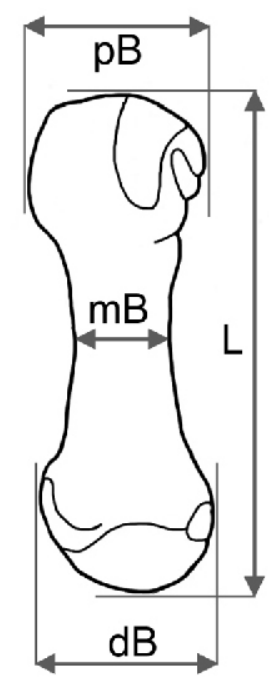
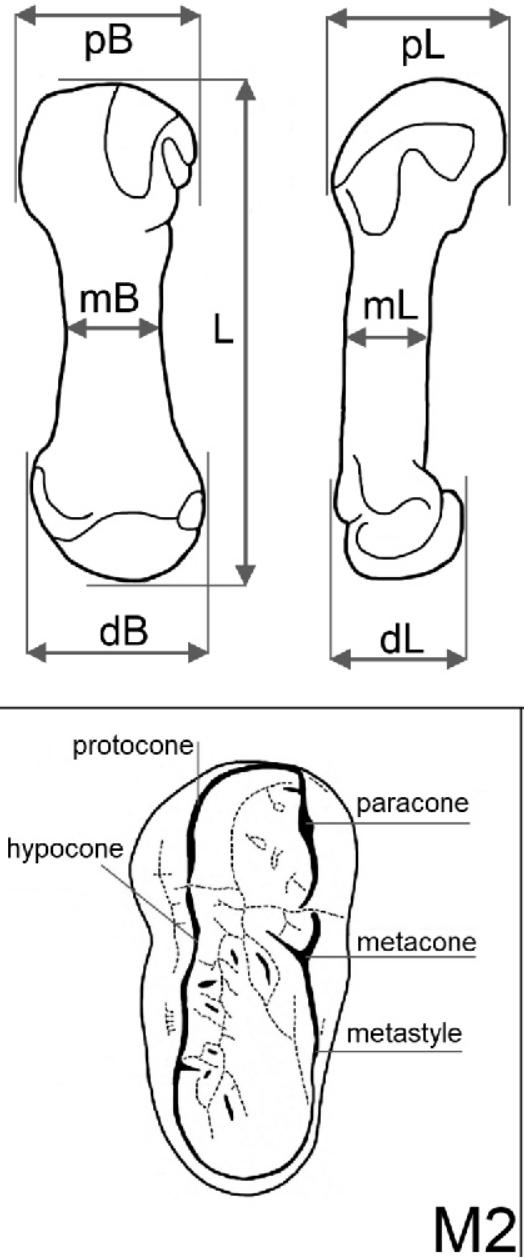
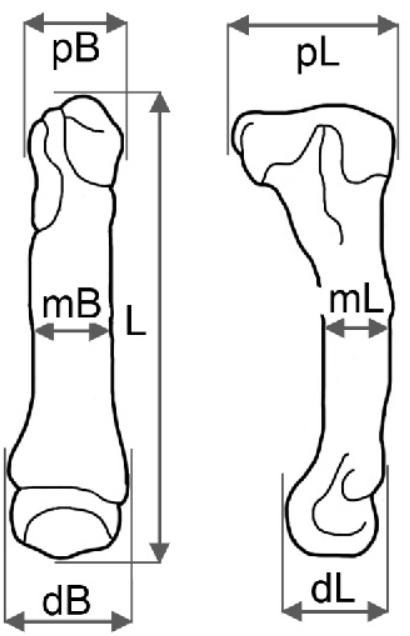

mt 2

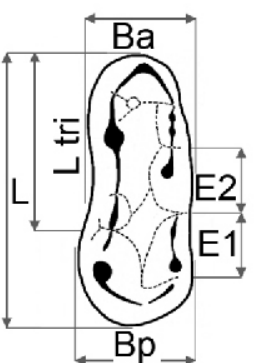

$\mathrm{Bp}$

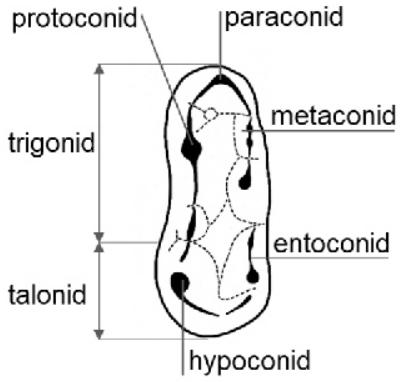

$\mathrm{m} 1$

Fig. 2. Scheme of measurements of bear teeth and postcranial bones

M2: $\mathbf{L}$ - total length, $\mathbf{L}$ pa - paracone length, $\mathbf{L}$ me - metacone length, Ba - trigon breadth, bp - talon breadth; $\mathbf{m} 1$ : $\mathbf{L}-$ total length, $\mathbf{L}$ tri trigonid length, E1 - entoconid 1 length, E2 - entoconid 2 length, Ba - trigonid breadth, Bp - talonid breadth; metapodials (mc 1, mc 5, and $\mathrm{mt} 2$ ): $\mathbf{L}$ - total length, $\mathbf{p L}$ - proximal epiphysis depth, $\mathbf{p B}$ - proximal epiphysis breadth, $\mathbf{m L}$ - anteroposterior shaft length, $\mathbf{m B}$ - minimal shaft breadth, $\mathbf{d L}$ - distal epiphysis depth, $\mathbf{d B}$ - distal epiphysis breadth

Arsuaga, 2001); Untermassfeld (Musil, 2001); West Runton (Lewis et al., 2010).

3. Ursus deningeri: Chateau (Athen, 2007); C 718 cave, Chlum 1 and 4 caves (Wagner and Čermák, 2012); Eichorn cave (Athen, 2007); Gombasek (Gombaszög), Koněprusy caves, and Kövesvárad (Wagner and Čermák, 2012); Kozi Grzbiet (this work), Mosbach 2 (Athen, 2007); Petralona cave (Kurtén and Poulianos, 1977); Stránská Skála (Musil, 1972); Tunel Wielki cave (this work); Westbury-sub-Mendip (Athen, 2007).

\section{RESULTS}

All material studied is stored at the Institute of Systematics and Evolution of Animals, Polish Academy of Sciences, Kraków. The publication concerns only material from the oldest layers of the cave. Most of the material comes from clay loam and the adjacent layer of analogous debris. That is, they come from mixed layers. M2 and mc 3 come from a layer of red clay with rock rubble, while a smaller $\mathrm{m} 1$ was from the bottom layer of limestone debris with red silt. Additionally, a left $\mathrm{mt} 2$ was found in the lower part of the loess with rock rubble from the front of the inside part of the chamber.
The ursid material from Jasna Strzegowska cave comprises 24 specimens. Among them, left $\mathrm{C} 1$, right M2, and 16 postcranial elements (right calcaneus without proximal epiphysis, left $\mathrm{mc} 3$, right $\mathrm{mc} 5$, two left $\mathrm{mt} 2$, right triquetrum, right trapezium, right navicular, right hamatum and seven, mostly strongly damaged phalanges were assigned to $U$. etruscus (total 18 teeth and bones). All other remains, namely five isolated teeth (right, worn 13 , left $\mathrm{C} 1$, left and right $\mathrm{m} 1$ and crown fragment of left m2) were classified as U. deningeri. Finally, two milk canines, due to lack of any diagnostic metric or morphological features, were tentatively identified as Ursus sp.

\section{URSUS DENINGERI VON REICHEANU, 1904}

A single right I3 (ISEZ MF/7399) from the Jasna Strzegowska cave is represented only by a damaged crown, with broken buccal part and small part of the root. This large, caniniform incisor has the crown situated at an angle of $40^{\circ}$ to the axis of the root; the crown itself appears in the medial-lingual part of the point. In terms of its cross-section, the crown is compressed in a longitudinal direction. The medial and distal ridges appear less sharply in its apex area than in the U. etruscus. 
The distal edge gradually rises against the lingual crown surface. A little below the tip, the medial edge divides downwards into two divergent parts, which enclose a gusset-like depression. However, this division tends to be more clearly visible than that of $U$. etruscus. The medial and distal edge bends or kinks at the base lingually and merges into a cingulum that terms inside of the entire tooth. The I 3 from Jasna Strzegowska cave has a well-developed lingual edge and a fossa lunaris which occurs as a clearly visible pit on the mesial side of the tooth. The cingulum in $U$. etruscus is very weak and sometimes absent. In standard I3 of mid-late Middle Pleistocene U. deningeri, the anterior and posterior edges delimit a somewhat recessed field with the lingual cingulum. In the hollow, small side stools often develop on the medial base of the main cusp and occasionally on its distal base. The medial stool always rises at the point where the lingual part of the edge joins the cingulum. It tends to be less sharply opposed to this than to the downward inclination of the main point stacked side stools on the distal base. The upper one is separated from the descending edge by a notch, the lower one seems to represent an elevation of the cingulum. This stool-like elevation of the cingulum apparently has a local bulge in the base of the crown, while the other cusp is otherwise below the distal edge and tends to reach the deepest one.

The development of 13 from Jasna Strzegowska cave is similar to that of $U$. deningeri; this specimen also differs from spelaeoid bears in a less developed lingual edge and fossa lunaris, lack of any additional enamel structures, and overall a less massive and more curved crown. As for the 13 of $U$. a. suessenbornensis, there is no lingual edge and no fossa lunaris, which are present on the tooth analysed. The measured specimen (length $12.78 \mathrm{~mm}$, breadth $10.97 \mathrm{~mm}$ ) lies within the range of $U$. deningeri, while $\mathrm{I} 3$ is larger and more massive than the $I 3$ of $U$. etruscus (Figs. 3 and 4 ; Table 1). Only the largest I3 of $U$. etruscus matches in size the 13 from Jasna Strzegowska cave, but morphological features excluded assignation to this species.

There are two $\mathrm{m} 1$ of different sizes. Dimensions of the smaller, right $\mathrm{m} 1$ (ISEZ MF/7402) fall into the variability of extant $U$. a. arctos and small teeth of $U$. deningeri, and are much smaller than $\mathrm{m} 1$ of $U$. ex gr. spelaeus and $U$. a. priscus. The lingual margin is straight, while the anterior one is sharply pointed. The buccal margin of the trigonid is slightly convex, and gently link with the talonid which is moderately enlarged. The tooth is elongate and moderately wide. All main cusps are connected by a thick crest which follows the tooth outline. The talonid cusps are situated at modest distances from each other. The para- and protoconid form an open angle. There is one, moderately large metastylid on the crest between the para- and metaconid (morphotype 1). A single large metaconid is connected with the mesial metastylide which is turned medially. The double entoconid is composed of a large, dominant entoconid 1 and strongly associated with entoconid 2 . The entire entoconid complex forms a gradually descending crest with entoconid 2 bearing a longer, further diversified mesial arm (morphotype A2). Before entoconid 2 a rudimentary cusplet can be detected, but it is probably not related to the entoconide complex. A clearly visible, double and rounded entyphoconid occurs between the hypo- and entoconid. On the interior slope of the hypoconid, two very delicate pillar-like reinforcements occur; however there are poorly developed, so there are neither entoconid pillars, nor mesoconid and median crests. The low and elongated hypoconulid is poorly defined, and the cingulum is weakly developed. Measurements: 1 - $25.8 \mathrm{~mm}, 2$ $14.5 \mathrm{~mm}, 3-11.4 \mathrm{~mm}, 4-10.0 \mathrm{~mm}, 6-13.2 \mathrm{~mm}$.

The second left $\mathrm{m} 1$ (ISEZ MF/7401) is larger and its size falls within the variability of $U$. deningeri, $U$. ex gr. spelaeus and $U$. a. priscus, and exceeds the values of extant $U$. a. arctos. The buccal margin of the trigonid is almost straight, while the lingual one is slightly convex at the connection with the talonid, and its anterior margin is blunt. The wide talonid rises considerably from the trigonid and its buccal margin forms a semi-circular arch, while the lingual margin is only slightly convex. The tooth looks elongate and moderately massive. All main cusps are connected by a thick and low crest which follows the tooth outline. The talonid cusps are situated quite some distance from each other. The para- and protoconid form an open angle, but the $\mathrm{V}$-shaped valley that distinguishes both cusps is much narrower and deeper. There is one, large metastylid on the crest between the para- and metaconid (morphotype 1). A single large metaconid is connected with the mesial metastylid, which is oriented medially. The triple entoconid consists of a large, dominant entoconid 1, strongly associated with entoconid 2 and smaller entoconid 3 (morphotype A3). The entire entoconid complex forms a gradually descending crest with the entoconid 3 bearing a long, further diversified mesial arm. A single and elongated entyphoconid occurs between the hypo- and entoconid. On the interior slope of the hypoconid, there are a few delicate pillar-like reinforcements, while there are no entoconid pillars, no mesoconid and no median crests. A low and elongated hypoconulid is recognisable, and a cingulum is weakly developed. Measurements: $1-29.4 \mathrm{~mm}, 2-16.2 \mathrm{~mm}$, $3-6.3 \mathrm{~mm}, 4-3.3 \mathrm{~mm}, 5-11.8 \mathrm{~mm}, 6-15.3 \mathrm{~mm}$. The larger tooth from Jasna Strzegowska cave fits well with the size range of $U$. deningeri, while the smaller one is in the range of $U$. a. suessenbornensis; both teeth clearly exceed the dimensions of $\mathrm{m} 1$ of $U$. etruscus (Figs. 3 and 4; Table 1).

Because of their morphology, both $\mathrm{m} 1$ from Jasna Strzegowska cave were previously attributed to Ursus sp. or Ursus spelaeus. Our analysis showed that both these teeth should be classified as belonging to $U$. deningeri based on: (1) the entoconid complex (adequately double and triple) forming a gradually descending crest with the largest entoconid 1 , and with entoconid 2 bearing a long, further diversified, mesial arm; (2) the mesial metastylid oriented medially from the metaconid; (3) the main cusps, especially on the talonid, are placed farther away than in the arctoid bear; (4) the buccal wall of the trigonid bulges (very gently in the smaller $\mathrm{m} 1$, more visibly in the larger tooth) at the metaconid/metastylid boundary; (5) the distal part of the paraconid is less medial-wards turned and has a more laterally extended medial slope; (6) a relatively wide talonid. Simultaneously, their classification as $U$. ex gr. arctos should be rejected, even if some morphometric values show similarity to those of this bear. Both teeth lack some features typical of $U$. ex gr. arctos: (1) the double entoconid complex is usually composed from a large dominant entoconid 1 and much smaller entoconid 2 with a short mesial arm; (2) lack of continuity between the mesial metastylid and the metaconid; (3) wider placement of the talonid cusps; (4) more sharply pointed anterior margin which is blunt in arctoid bears; (5) the mesial metastylid continues mesially or mesio-laterally; (6) the buccal wall is straight, without apparent bulging on the metaconid/metastylid boundary; (7) the distal part of the mesially shifted paraconid is turned more medially; (8) the talonid in relation to the trigonid is not so expanded and is moderately broad. 

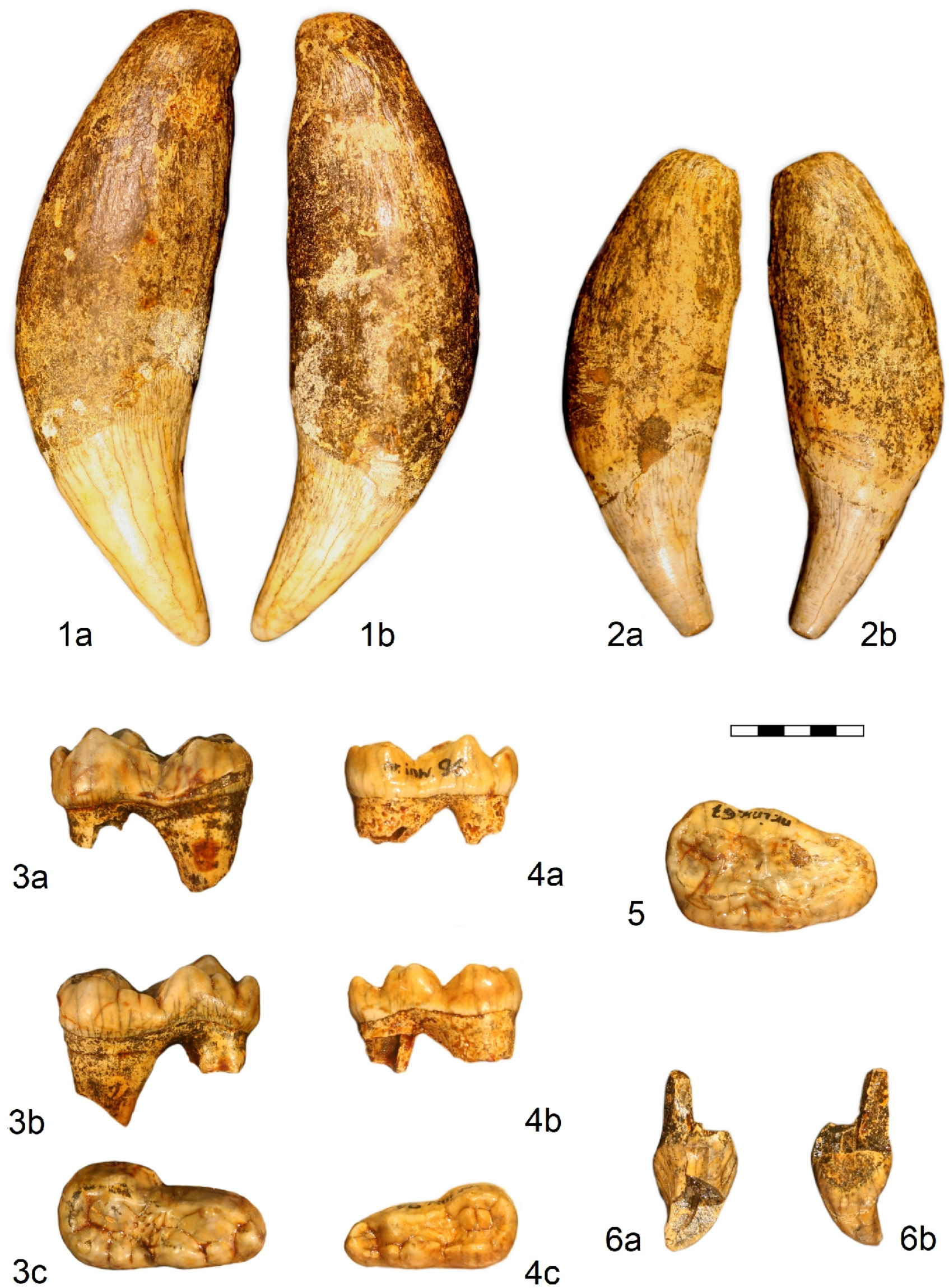

Fig. 3. Teeth of ursids from Jasna Strzegowska cave

Ursus deningeri: 1 - left C1 (ISEZ MF/7400), 3 - left m1 (ISEZ MF/7401), 4 - right m1 (ISEZ MF/7402), 6 - right I3 (ISEZ MF/7399); Ursus etruscus: 2 - left C1 (ISEZ MF/7395), 5 - right M2 (ISEZ MF/7394) (occlusal view); all teeth shown at the same scale, scale bar $20 \mathrm{~mm}$; a - buccal view, b - lingual view, c - occlusal view 

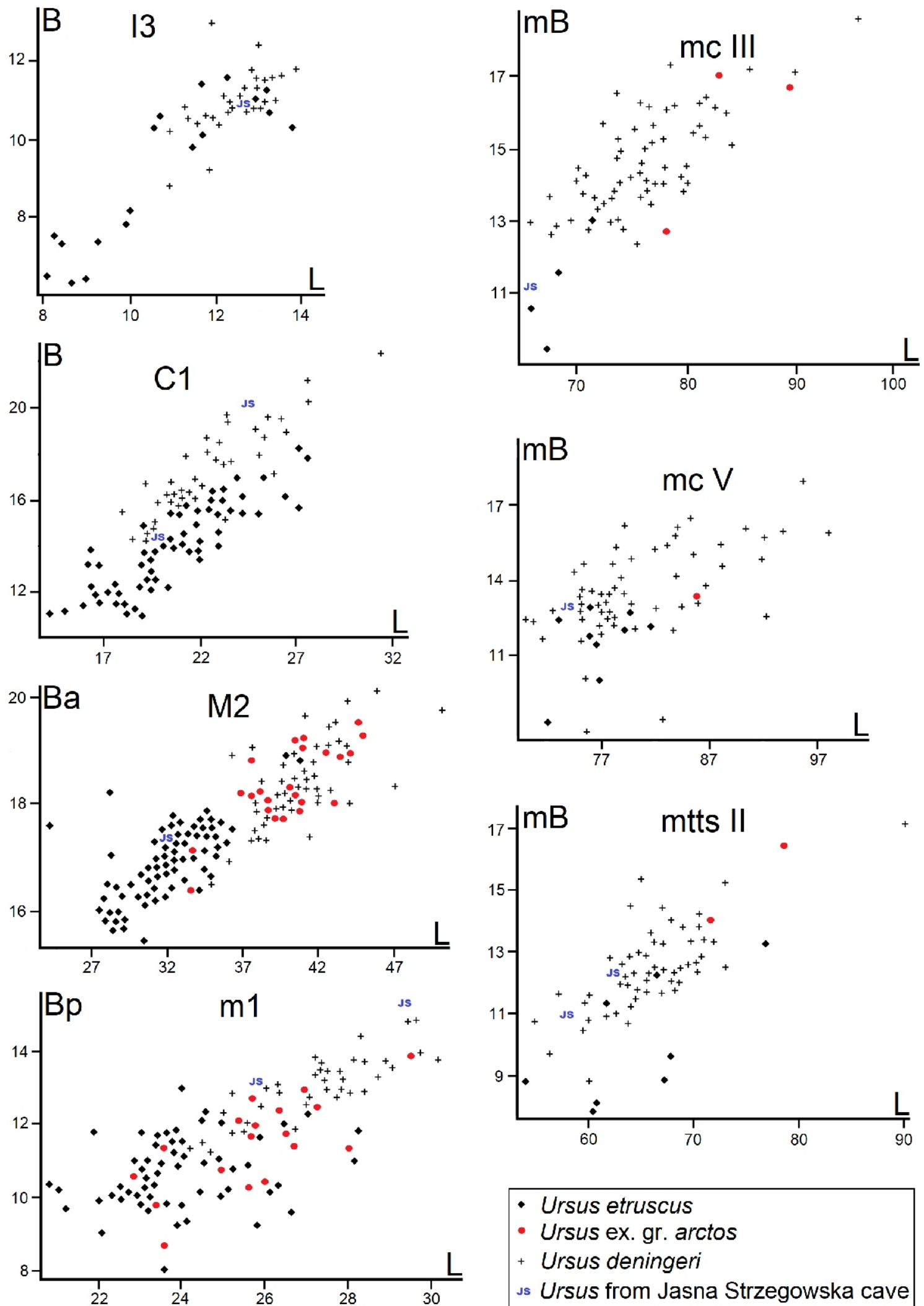

- Ursus etruscus

- Ursus ex. gr. arctos

+ Ursus deningeri

ss Ursus from Jasna Strzegowska cave

Fig. 4. Length of teeth and metapodials plotted against different breadth measurements $(B-$ breadth, $B a-$ anterior breadth, $\mathrm{Bp}$ - posterior breadth, $\mathrm{mB}$ - minimal shaft breadth) based on Early and early Middle Pleistocene material of Ursus etruscus, Ursus ex gr. arctos, Ursus deningeri and Ursus from Jasna Strzegowska cave 
Length of teeth and indices distinguishing different bear species based on Early and early Middle Pleistocene materials of Ursus etruscus, Ursus ex gr. arctos, Ursus deningeri and Ursus from Jasna Strzegowska cave

\begin{tabular}{|c|c|c|c|c|c|c|c|c|c|c|c|}
\hline & \multirow{2}{*}{ JSJ } & \multirow{2}{*}{ JSJ } & \multicolumn{3}{|c|}{ U. ex gr. arctos } & \multicolumn{3}{|c|}{ U. etruscus } & \multicolumn{3}{|c|}{ U. deningeri } \\
\hline & & & $\mathrm{M}$ & variation & $\mathrm{N}$ & $\mathrm{M}$ & variation & $\mathrm{N}$ & $M$ & variation & $\mathrm{N}$ \\
\hline \multicolumn{12}{|c|}{13} \\
\hline $\mathrm{L}$ & 12.8 & & & & & 10.4 & $6.0-13.8$ & 18 & 12.5 & $10.9-14.2$ & 30 \\
\hline$B$ & 11.0 & & & & & 9.1 & $6.3-11.6$ & 18 & 11.1 & $8.8-13.1$ & 30 \\
\hline$B / L$ & 86.0 & & & & & 88.5 & $74.6-105.0$ & 18 & 88.9 & $78.0-109.2$ & 30 \\
\hline \multicolumn{12}{|c|}{$\mathrm{C} 1$} \\
\hline L & 24.5 & 19.7 & & & & 20.6 & $14.2-27.6$ & 60 & 22.6 & $18.0-31.4$ & 40 \\
\hline$B$ & 20.2 & 14.6 & & & & 14.0 & $11.0-18.2$ & 60 & 17.3 & $14.3-22.4$ & 40 \\
\hline $\mathrm{B} / \mathrm{L}$ & 82.5 & 74.0 & & & & 68.0 & $58.0-84.0$ & 60 & 77.0 & $65.2-87.0$ & 40 \\
\hline \multicolumn{12}{|c|}{ M2 } \\
\hline $\mathrm{L}$ & 32.1 & & 40.0 & $33.7-45.0$ & 23 & 32.0 & $24.2-40.7$ & 74 & 40.9 & $34.9-50.1$ & 47 \\
\hline $\mathrm{Ba}$ & 18.7 & & 20.6 & $16.8-23.0$ & 23 & 17.8 & $14.9-21.7$ & 74 & 20.8 & $17.1-24.2$ & 47 \\
\hline $\mathrm{Ba} / \mathrm{L}$ & 58.3 & & 51.7 & $46.5-57.5$ & 23 & 56.2 & $49.0-79.3$ & 74 & 51.1 & $44.0-60.1$ & 47 \\
\hline \multicolumn{12}{|c|}{$\mathrm{m} 1$} \\
\hline $\mathrm{L}$ & 25.8 & 29.4 & 25.8 & 22.9-29.5 & 18 & 24.0 & $20.9-28.2$ & 59 & 27.5 & $24.2-31.5$ & 42 \\
\hline $\mathrm{Bp}$ & 13.1 & 15.3 & 11.5 & $8.7-13.9$ & 18 & 10.7 & $8.1-13.0$ & 59 & 13.3 & $11.2-18.1$ & 42 \\
\hline $\mathrm{Bp} / \mathrm{L}$ & 50.8 & 52.1 & 44.4 & $36.9-49.4$ & 18 & 44.8 & $34.1-54.2$ & 59 & 48.3 & $41.5-60.5$ & 42 \\
\hline
\end{tabular}

JSJ - Jasna Strzegowska cave, L - length, B - breadth, Ba - anterior breadth, Bp - posterior breadth

\section{URSUS ETRUSCUS CUVIER, 1823}

There are two isolated canines among the bear material from Jasna Strzegowska cave, both well-preserve; only the smaller one (ISEZ MF/7395) has the tip shredded off. Based on the relatively weak curvature of the crown and the less elliptical shape of the root, the small isolated canine can be regarded as a lower canine. The larger tooth (ISEZ MF/7400) is strong and robust (length $24.5 \mathrm{~mm}$, breadth $20.2 \mathrm{~mm}$ ), curved moderately distally and weakly flattened bucco-lingually. The crown in relation to the root is proportionally short, with smooth distal edges, which are accompanied by hollows. Smaller tooth (length $19.7 \mathrm{~mm}$, breadth $14.6 \mathrm{~mm}$ ) differs in some minor morphological features.

Because of the lack of clearly defined diagnostic characters, it is not easy to distinguish different bear forms by their canines. Additionally, in contrast to the cheek teeth, canines are highly dimorphic. In the material from Mosbach 2 (600-550 ka), the upper canine breadth was $17.3-20.5 \mathrm{~mm}$ in $\hat{\partial} \hat{\sigma}(\mathrm{n}=8)$ and 13.3-16.7 mm in 우 $(n=10$; Baryshnikov, 2006). The substantial size difference between the two canines from Jasna Strzegowska cave might be interpreted as a sign of sexual dimorphism. We can distinguish $U$. deningeri and $U$. etruscus by their average size values. These measurements reflect that $U$. deningeri possessed more robust canines than $U$. etruscus, the sexual dimorphism in canine size in $U$. deningeri being more developed. However, there is also an overlap, and $\hat{\partial} \hat{\partial}$ canines of $U$. etruscus can be placed within the size range of $q 9+\mathrm{ca}-$ nines of $U$. deningeri (Figs. 3 and 4; Table 1).

However, we also found some morphological features which allow us to attribute both canines to different taxa. The small size and relatively slender build cannot give a clear answer as regards taxonomic attribution. However, the smaller canine possesses some additional, more arctoid-like characteristics which occur also in $U$. etruscus, but in $U$. deningeri are much rarer or more weakly developed. Firstly, the root is elongated and less massive in deningeroid and spelaeoid bears, while it is shorter and more massive in arctoid bears, a feature also noted for $U$. etruscus. The second character is the presence of a thin, well-developed inner enamel crest running along the entire crown length, from the top to the base; this is typical of arctoid bears (Rode, 1935). While some authors doubt that this feature allows clear discrimination, our observations show that it occurs in early Middle Pleistocene $U$. deningeri only rarely, and is weakly developed. The last character is the blunt top of the larger canine, while upper canines of arctoid bears usually en in sharp points. Unfortunately, the case smaller canine has a worn top so it is impossible to detect this feature. Based on the reasons noted above, we attribute the larger canine (ISEZ MF/7400) from Jasna Strzegowska cave to $U$. deningeri and the smaller one (ISEZ MF/7395) to $U$. etruscus.

An isolated M2 (ISEZ MF/7394) belongs to an adult animal, and no fine morphological structures are preserved due to abrasion. The crown has an elongated oval outline, with all main cusps low and expanded, so the chewing surface is broad and low $(1-32.1 \mathrm{~mm}, 2-9.8 \mathrm{~mm}, 3-8.9 \mathrm{~mm}, 4-18.7 \mathrm{~mm}, 5-$ $16.3 \mathrm{~mm}$ ). In occlusal view, the tooth possesses a broad and much expanded trigon as well as a very short talon, which quickly narrows. The buccal wall of the largest cusp, the paracone, forms a rectangular, smooth area which rises gently to the buccal margin. The lingual wall forms a much smaller but similarly smooth area. The smaller and morphologically similar metacone is separated from the paracone by a wide, shallow and U-shaped valley. A thick, well-defined ridge rises from the apex of the metacone to the trigon. The lingual main cusp, the protocone, is elongate and low, while the mesocone and hypocone are weakly developed, low and rounded. All three cusps are closely associated, and their apices are connected by a thin ridge. The anterior part of the protocone is connected with the anterior ridge which forms a thick and high wall, which 

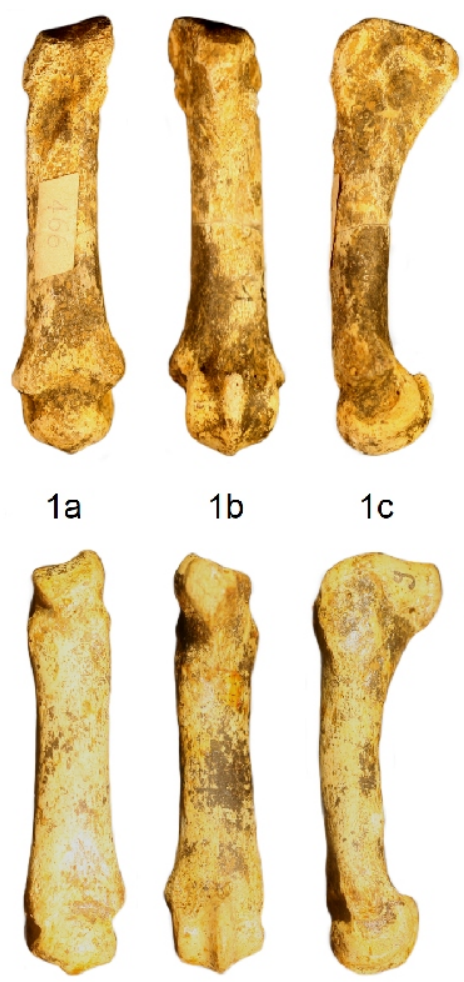

$1 b$

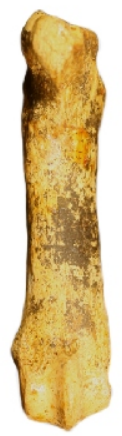

$3 a$ 1c

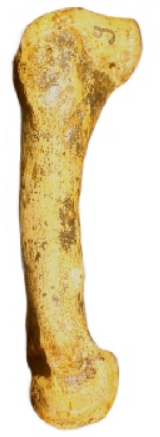

3c

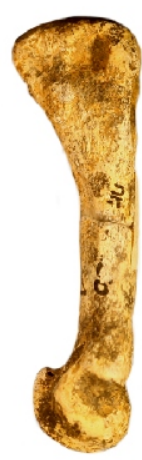

$1 d$

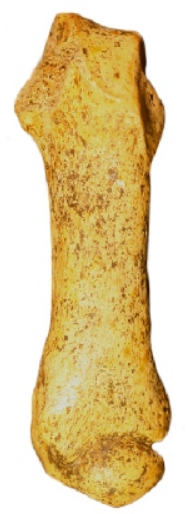

$2 a$

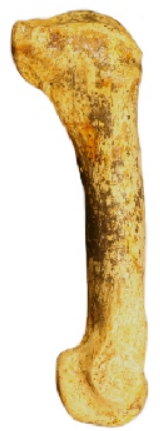

$3 d$

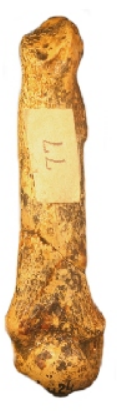

$4 a$

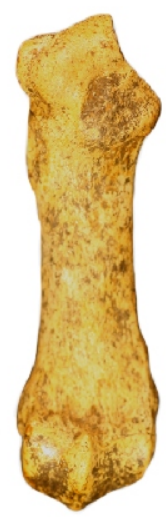

$2 b$

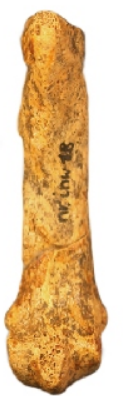

$4 b$

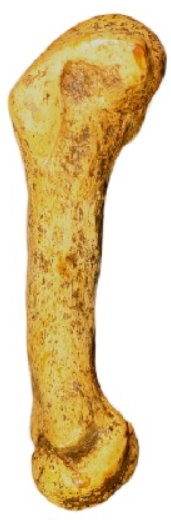

2c

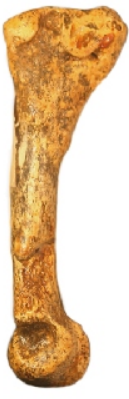

4c

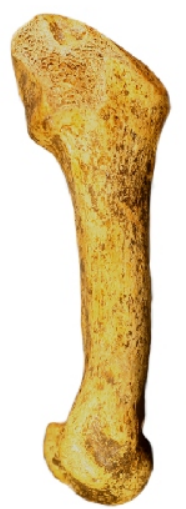

$2 d$

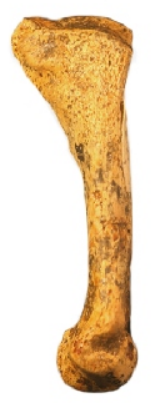

4d

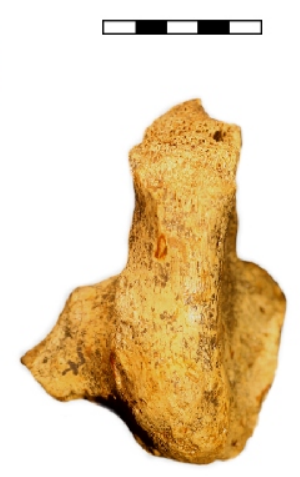

$5 a$

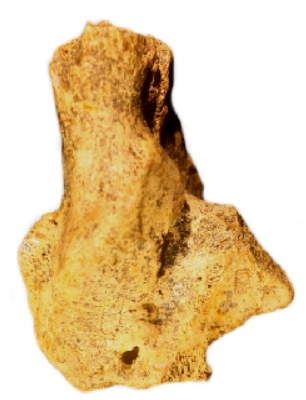

$5 b$

Fig. 5. Postcranial bones of Ursus etruscus from Jasna Strzegowska cave

1 - left mc 3 (ISEZ MF/7392), 2 - right mc 5 (ISEZ MF/7396), 3 - left mt 2 (ISEZ MF/7397), 4 - left mt 2 (ISEZ MF/7393), 5 - right calcaneus (ISEZ MF/7398); scale bar $25 \mathrm{~mm}$, a - dorsal view, b - ventral view, c - outer view, d - inner view, e - articulation view

collars the anterior parts of the talon and the paracone, but is not connected with this cusp. Despite the trigon broadness, the inner field is elongated but narrow and almost smooth. The tooth bears an moderately developed cingulum approximately below the protocone complex and anterior half of the hypocone on the lingual side, and below the paracone on the buccal one. These two parts were connected by a mesial margin. There is no parastyle present at the contact between the mesial margin and paracone but the cingulum gets stronger in this region. No accessory cusps are evident on the buccal side. A distal cingulum is weakly developed, forming a low ridge, which collars almost the entire talon, but is not connected with the metacone. The rounded and restricted talon field is smooth, with only a few, weakly developed lines.

A morphological analysis according to Rabeder (1999) shows a very low stage of evolution and high primitivism of the tooth analysed. All morphotypes characterising the M2 were regarded as the most primitive ones: parastyle - A1, mesostyle 0 , paracone pillar $-A$, metaloph -0 , posterolophe -0 , talon field $-A$, metastyle -0 , posthypocone -0 , distal cingulum $-A$, protocone internal slope -0 , lingual cingulum -0 . The M2 from Jasna Strzegowska cave is as primitive as all comparative specimens of $U$. a. suessenbornensis and more primitive than the $M 2$ of $U$. deningeri in all individual characteristics. In size, the tooth matches well the $U$. etruscus range and lies outside those of both $U$. deningeri and $U$. a. suessenbornensis (Figs. 3 and 4; Table 1).

The right calcaneus (ISEZ MF/7398) is strongly damaged, with half of the tuber calcanei and the medial process chipped off; therefore it is impossible to estimate the maximum length or breadth of the bone (Fig. 5). However, the remaining part, and comparison with the complete calcanei of other bears, allows estimation of the total length as $\sim 70-80 \mathrm{~mm}$. This value lies in the range of deningeroid bears, and is also comparable with recent $U$. a. arctos and $U$. etruscus dimensions. Apart from the size, the morphology differs slightly from the calcaneus of deningeroid bears. The medial process is broad but relatively short, triangular and situated almost vertically to the corpus, which is very massive in the anterior-posterior direction. Almost the entire surface of the medial process is covered by an oval, broad and shallow facies articularis astragali medialis. The lateral process forms a thin and high crest running from the distal end to halfway along the corpus. Running transversally, the broad and shallow facies articularis astragali lateralis is separated from the facies articularis astragali medialis by a deep and wide groove. An oval and deep facies articularis cuboidea is connected distally with the facies articularis astragali medialis. The crescentic and flat sulcus tendinis musculi flexoris hallucis longis is elongate and medially widened. In comparison to the calcaneus from Jasna Strzegowska cave, the heel bone of the deningeroid bear differs by the following features: (1) the medial process is elongate and rectangular, with the distal end oriented more medial-proximally; (2) the facies articularis astragali medialis placed on the medial process is rectangular, rather flat and its margin forms a thin but sharply pointed ridge, which collars the whole surface; (3) the lateral process is more pronounced, the flat facies articularis astragali medialis being longer and running more obliquely; (4) the facies articularis cuboidea is shallower and does not contact with the facies articularis astragali medialis.

The well-preserved, left mc 3 (ISEZ MF/7392) is a small and proportionally gracile bone $(1-64.5 \mathrm{~mm}, 2-19.9 \mathrm{~mm}, 3-$ 
Length of metapodials and indices distinguishing different bear species based on Early and early Middle Pleistocene material of Ursus etruscus, Ursus ex gr. arctos, Ursus deningeri and Ursus from Jasna Strzegowska cave

\begin{tabular}{|c|c|c|c|c|c|c|c|c|c|c|c|}
\hline & \multirow{2}{*}{ JSJ } & \multirow{2}{*}{ JSJ } & \multicolumn{3}{|c|}{ U. ex gr. arctos } & \multicolumn{3}{|c|}{ U. etruscus } & \multicolumn{3}{|c|}{ U. deningeri } \\
\hline & & & $\mathrm{M}$ & variation & $\mathrm{N}$ & $M$ & variation & $\mathrm{N}$ & $M$ & variation & $\mathrm{N}$ \\
\hline \multicolumn{12}{|c|}{$\mathrm{mc} 3$} \\
\hline L & 64.5 & & 83.7 & $77.8-90.1$ & 3 & 67.1 & $64.5-70.4$ & 5 & 76.2 & $64.4-96.6$ & 62 \\
\hline $\mathrm{pB}$ & 13.4 & & 19.9 & $16.5-23.4$ & 3 & 14.5 & $12.3-16.8$ & 5 & 18.3 & $15.0-23.6$ & 62 \\
\hline$m B$ & 11.1 & & 15.2 & $12.7-17.0$ & 3 & 11.0 & $9.5-13.0$ & 5 & 14.8 & $12.4-18.6$ & 62 \\
\hline $\mathrm{mB} / \mathrm{L}$ & 17.2 & & 15.2 & $14.3-16.0$ & 3 & 14.3 & $12.4-17.3$ & 5 & 16.1 & $12.8-19.5$ & 62 \\
\hline$d B$ & 18.0 & & 23.3 & $20.2-26.0$ & 3 & 17.4 & $15.8-19.3$ & 5 & 22.7 & $19.6-27.5$ & 62 \\
\hline$d B / L$ & 27.9 & & 27.8 & $26.0-29.1$ & 3 & 25.8 & $23.9-27.4$ & 5 & 30.0 & $26.5-35.5$ & 62 \\
\hline \multicolumn{12}{|c|}{$\mathrm{mc} 4$} \\
\hline L & 74.5 & & 77.0 & $67.9-86.1$ & 2 & 76.5 & $63.0-81.8$ & 10 & 81.0 & $70.4-98.3$ & 58 \\
\hline $\mathrm{pB}$ & 24.6 & & 23.7 & $20.5-27.0$ & 2 & 23.4 & $20.1-25.3$ & 9 & 28.7 & $24.1-36.6$ & 58 \\
\hline $\mathrm{mB}$ & 16.0 & & 12.3 & $8.2-16.3$ & 2 & 14.1 & $11.1-16.0$ & 10 & 16.6 & $10.9-21.0$ & 58 \\
\hline $\mathrm{mB} / \mathrm{L}$ & 21.5 & & 15.5 & $12.1-19.0$ & 2 & 18.7 & $15.7-21.2$ & 10 & 20.5 & $13.8-24.3$ & 58 \\
\hline$d B$ & 23.7 & & 23.0 & $19.8-26.1$ & 2 & 20.8 & $17.5-23.0$ & 10 & 16.6 & $10.9-21.0$ & 58 \\
\hline$d B / L$ & 31.8 & & 29.7 & $29.1-30.3$ & 2 & 27.9 & $26.1-30.1$ & 10 & 33.5 & $29.2-33.5$ & 58 \\
\hline \multicolumn{12}{|c|}{$\mathrm{mt} 2$} \\
\hline L & 57.8 & 62.7 & 75.1 & $71.7-78.6$ & 2 & 64.6 & $54.0-76.9$ & 8 & 66.2 & $54.8-90.0$ & 54 \\
\hline $\mathrm{pB}$ & 10.5 & 13.3 & 15.4 & $14.0-16.7$ & 2 & 13.9 & $10.0-17.7$ & 8 & 15.2 & $10.9-21.6$ & 54 \\
\hline $\mathrm{mB}$ & 10.9 & 12.4 & 15.2 & $14.0-16.4$ & 2 & 10.1 & $7.9-13.2$ & 8 & 12.5 & $8.8-17.1$ & 54 \\
\hline $\mathrm{mB} / \mathrm{L}$ & 18.9 & 19.8 & 20.2 & $19.5-20.9$ & 2 & 15.5 & $13.0-18.5$ & 8 & 18.9 & $14.6-23.6$ & 54 \\
\hline$d B$ & 17.2 & 16.7 & 22.5 & $21.9-23.2$ & 2 & 17.5 & $12.5-21.1$ & 8 & 19.5 & $15.8-27.6$ & 54 \\
\hline$d B / L$ & 29.8 & 26.6 & 30.0 & $29.5-30.5$ & 2 & 27.1 & $23.2-29.2$ & 8 & 29.4 & $24.8-34.0$ & 54 \\
\hline
\end{tabular}

JSJ - Jasna Strzegowska cave, L - length, pB - proximal breadth, mB - minimal shaft breadth, dB - distal epiphysis breadth

$13.4 \mathrm{~mm}, 4-8.9 \mathrm{~mm}, 5-11.1 \mathrm{~mm}, 6-15.7 \mathrm{~mm}, 7-18.0 \mathrm{~mm})$. The proximal articulation is set nearly at right angles to the end of the shaft, the dorsal face expanding considerably more than the posterior (Fig. 5). It is vertically convex, transversely concavo-convex. On its inner side, there is a broad oval surface set on a tuberosity for articulation with the overhanging portion of the mc 2. These two articular surfaces are divided from each other by a well-marked ridge. On the external side, there are two concave surfaces which overhang and articulate with the mc 4 . They are not so deeply concave, and are more confluent than those of the mc 2. On the anterior surface, a shallow groove of the proximal epiphysis runs diagonally, and the trapezoidal ligament was attached to its upper part. The entire head of the bone is roughened for the reception of the ligaments binding the bone to the carpus and its fellow metacarpals. The shaft presents a triangular section proximally, and it is nearly circular in the middle and distally. A slight palmar ridge is developed behind, at the point where it joins the distal articulation, and it is flattened in front. The distal epiphysis is bulb-shaped, and divided from the epiphyseal line of the shaft by deep dorsal and lateral depressions. The distal articulation is epiphyseal and symmetrical, having the inner tuberosity larger than the external one. On the palmar or inferior surface, they develop a short ridge along the median line. This line fits into the palmar notch of the first phalanges. On either side of it lies a sesamoid bone to which almost all tendons of the adductor and flexor muscles were fixed, for the movement of the metacarpals. At the point where the shaft joins the distal end, there is a tuberosity which catches the sides of the phalangeal articulations. In general appearance, the distal articulation is almost straight on the inner side and strongly curved on the external side.
In size, mc 3 (ISEZ MF/7392) from Jasna Strzegowska cave falls within the lowermost values of $U$. deningeri and $U$. etruscus, and is smaller from that of $U$. a. suessenbornensis (Figs. 4 and 5; Table 2). Its proportions are comparable with those of $U$. deningeri and $U$. etruscus, however the plumpness indexes for the shaft and distal epiphysis is closer to the second species. Morphologically, the mc 3 analysed differs slightly from that of $U$. deningeri in two less expanded concave surfaces on the proximal end for the contact of $\mathrm{mc} 4$.

An intact, right mc 5 (ISEZ MF/7396) is the largest and the most massive among all four preserved from Jasna Strzegowska cave $(1-74.5 \mathrm{~mm}, 2-27.0 \mathrm{~mm}, 3-24.6 \mathrm{~mm}, 4-$ $11.6 \mathrm{~mm}, 5-16.0 \mathrm{~mm}, 6-19.0 \mathrm{~mm}, 7-23.7 \mathrm{~mm}$ ), with the proximal epiphysis strongly thickened and flattened (Fig. 5). The proximal articulation for the hamatum forms a continuous surface with that of $\mathrm{mc} 4$, and like it is convex only in vertical direction and covers the entire end of the bone. The inter-metacarpal articulation is flattened, segmental in form, set at right angles to that for the hamatum, and interrupted inferiorly by a large ligamentary notch. In front it rises to an articular surface, which fits into a corresponding hollow in mc 4 . Both proximal articulation facets for the carpals IV-V run gently from anterior to posterior and protract medially. The medial articulation surface (for mc 4) shows two round lobes. The larger, anterior, lobe runs down distally into a triangular area. Externally, its head presents a large tuberosity which afforded attachment to the strong ligaments that bound the bone to the hamatum, cuneiform, and pisiform. On the palmar surface, there is also a large tuberosity. The proximal epiphysis is deeply convex and the anterior limit ends in an acute angle. Laterally, it develops a bulge and forms a semilunar convex surface. The shaft is proportion- 
ally shorter and more robust than triangular in section, to be more tapering, and to arch more decidedly in a palmar and outward direction than any other metacarpal bone. The distal epiphysis is strongly convex externally and concave internally, and the outer tuberosity is larger and set lower on the bone than the inner one. Its shape is developed according to the norm for ursids and it is split into two parts of different size by a crista. The medial part is narrower, while the palmar process is large and well developed. In size, the mc 5 analysed is placed within the range of $U$. deningeri, $U$. etruscus, and $U$. a. suessenbornensis (Figs. 4 and 5; Table 2). The massiveness of this bone slightly exceeds the values obtained for $U$. etruscus, especially the distal end. Morphologically, the mc 5 from Jasna Strzegowska cave differs from that of $U$. deningeri in the shape of the arch-like curvature which is less developed while the dorsal surface is more flattened.

There are two well-preserved $\mathrm{mt} 2$ from Jasna Strzegowska cave, which do not differ morphologically. The size difference is a result of sexual dimorphism, with the larger bone (ISEZ MF/7397) belonging to the male $(1-57.8 \mathrm{~mm}, 2-20.5 \mathrm{~mm}, 3-$ $10.5 \mathrm{~mm}, 4-7.7 \mathrm{~mm}, 5-10.9 \mathrm{~mm}, 6-13.9 \mathrm{~mm}, 7-17.2 \mathrm{~mm})$, and the smaller (ISEZ MF/7393) to the female $(1-62.7 \mathrm{~mm}, 2-$ $21.8 \mathrm{~mm}, 3-13.3 \mathrm{~mm}, 4-9.8 \mathrm{~mm}, 5-12.4 \mathrm{~mm}, 6-15.7 \mathrm{~mm}$, $7-16.7 \mathrm{~mm}$ ). The proximal articulation is formed by a medial concavity that is frontally bulged and posteriorly directed to the medial side (Fig. 5). It also narrows pointedly in its posterior direction, and has a triangular shape. Laterally, there are two well-marked surfaces, both concave and joined to $\mathrm{mt} 3$. The proximal articular surface for the cuneiform I is pronounced and its median ridge is strongly shifted dorsally, while frontally it is enlarged and curved. Medially, it forms a short constriction and a distal bulge. The articular surfaces for $\mathrm{mt} 3$ are separated from each other, and the posterior one is much larger and rounded. The proximal articulation facet for tarsal II is composed of two different areas, clearly separated by large, well-developed and rounded incisions that differ in size. Anterior part is strongly widened and curved, in shape a non-isosceles triangle. The posterior part is smaller and rectangular in shape. An elongate smaller indentation is shifted towards the medial side and is positioned centrally. The larger indentation is more oval-shaped, situated more laterally and runs anterior-medially. Medially, the articular surface is divided into two sides: frontally, the first one is horizontally elongated, stretching out and sloping to the medial plane. Behind, there is a flat and short end to the surface. Frontally, there is one concavity, similar to that described on the previous bone. The medial articulation is divided into two parts, a smaller anterior and a larger posterior one. The areas are separated by a semi-circular incision, strongly pleated at the base. The lateral indentation is similarly developed and also splits into two, differently-sized areas. The medial crest and a medial articulation facet slopes towards the medial side, and these are quite shallow and elongated. Mt 2 has a massive and curved diaphysis, front-distally flattened and rectangular. The distal articulation is relatively large, rounded, and irregular-shaped. The medial epicondyle is more prominent than the lateral one.

In size, both $\mathrm{mt} 2$ from Jasna Strzegowska cave fell into the size range of $U$. deningeri and $U$. etruscus, with the larger bone near the mean of both species (Figs. 4 and 5; Table 2). Their proportions are also comparable with those of $U$. deningeri and $U$. etruscus, however the plumpness indexes for the shaft and distal epiphysis are closer to deningeri. Morphologically, the $\mathrm{mt} 2$ analysed differs from $\mathrm{mt} 2$ of $U$. deningeri and $U$. etruscus by the following features: (1) the proximal articular facet of $\mathrm{mt} 3$ becomes smaller anteriorly and the proximal articulation slightly bends towards the anterior and lacks a deep incision on the dorsal margin; (2) the articular facet for the $\mathrm{mt} 3$ is smaller anteriorly.

\section{INTERPRETATION AND DISCUSSION}

Sawicki (1953) noted that most of the bones examined from the Jasna Strzegowska cave came from different layers of the cave, mainly 6 and 4 , which were re-deposited from the bottom of the cave. The upper layers, relatively rich in fauna, represent the Holocene and the Late Pleistocene, as shown by dating of a Saiga tatarica skull $(13,630 \pm 70$ years BP uncalibrated, Poz-26122, Nadachowski et al., 2016). The cranium came from loess deposits under a layer of soil (this is probably layer 6 according to Sawicki's (1953) nomenclature. The oldest layer (according to Sawicki (1953) layer 3-red-brown weathered clay) according to Mirosław-Grabowska and Cyrek (2009) came from probably a warm and humid period, most likely around the boundary of the Pliocene and early Pleistocene. There is strong frost-disturbance of silt in both the upper and lower parts. Analysis of the deposits show that they do not represent a continuous succession and thus the interpretation given is only tentative. The lower deposits preserved in the Jasna Strzegowska cave have characters of typical karst fillings in the form of red-brown clays. The lithology of this layer, and especially the high proportion of residual clay, the high iron content and the occurrence of mainly autogenic minerals indicate deposition during a warm and humid period, probably at the Pliocene-Early Pleistocene boundary (Mirosław-Grabowska and Cyrek, 2009). Additionally, Sawicki (1953) observed two levels of frost disturbances in the deposits. The lower level included an extrusion of sediments of layers 2 and 3 and deformation of layer 4 . The upper level was marked by the intrusion of some layer 4 deposits into the loess layers (Mirosław-Grabowska and Cyrek, 2009). Apart from the ursid bones described above, no older faunal elements have been found there. Therefore, the exact age of the material cannot be estimated.

The taxonomic position of bear remains from the Jasna Strzegowska cave has been interpreted differently in the past, they being attributed to Ursus sp. or U. spelaeus (Sawicki, 1953; Mirosław-Grabowska and Cyrek, 2009; Stefaniak et al., 2009). The material is not abundant, but is well-preserved, and it was attributed to $U$. etruscus based on the results of morphological analysis. From Poland, this species has been mentioned only once from the Early Pleistocene alluvial deposits of Zadębce (SE Poland; Prószyński, 1952). Later authors only cited the first mention (Kowalski, 1959; as Ursus sp. in Wolsan, 1989), but it has never been found again in Poland. Similarly, material from Zadębce was only mentioned as an advanced form, at an evolutionary level between that of Pliocene and Pleistocene bears (Prószyński, 1952). However, the material was never described in detail, so it is impossible to compare it with the bones from Jasna Strzegowska cave.

$U$. etruscus appeared in Eurasia $\sim 2.2-2.0 \mathrm{Ma}$ and is regarded as a typical Early Pleistocene faunal element and representative of a new ursine evolutionary lineage of Asiatic origin in Europe (Table 3; Rustioni and Mazza, 1993a, b; Wagner, 2010). Remains of this bear have been found at many localities across Eurasia dated between 1.8-1.3 Ma, such as Saint-Vallier (Viret, 1954; Argant, 2004), Puebla de Valverde (Kurtén and Crusafon-Pairó, 1977) and Dmanisi (Medin et al., 2019). In the evolutionary history of this species, four subspecies were described: (1) U. e. saintvallierensis Baryshnikov, 
Occurrence of Ursus etruscus in the Early Pleistocene of Eurasia

\begin{tabular}{|c|c|c|}
\hline Site & Age [Ma] & Lliterature \\
\hline Saint-Vallier & $2.2-2.0$ & Viret (1954); Argant (2004); Baryshnikov (2007) \\
\hline Puebla de Valverde & $2.2-2.0$ & Gautier and Heintz (1974); Kurtén and Crusafont-Pairó (1977) \\
\hline Dafnero 1 & $2.0-1.9$ & Koufos and Kostopoulos (2016); Koufos et al. (2018) \\
\hline Sesklon (cf.) & $2.0-1.9$ & Symeonidis (1992); Koufos and Kostopoulos (2016); Koufos et al. (2018) \\
\hline Chilhac 2 & $2.0-1.8$ & Boeuf (1997); Boivin et al. (2010) \\
\hline Valdarno & $1.9-1.8$ & $\begin{array}{c}\text { Forsyth Major (1887, 1890); Berzi (1966); Torre et al. (1993); Mazza and Rustioni (1992, 1994); } \\
\text { Rook et al. (2013) }\end{array}$ \\
\hline Vassiloudi & $1.9-1.8$ & Koufos and Kostopoulos $(1997,2016) ;$ Koufos et al. (2018) \\
\hline Olivola & $1.9-1.8$ & Mazza and Rustioni $(1992,1994)$ \\
\hline Val di Magra & $1.9-1.8$ & Forsyth Major (1890); Mazza and Rustioni $(1992,1994)$ \\
\hline Kisláng & $1.9-1.7$ & Jánossy (1986) \\
\hline Dmanisi & $1.9-1.7$ & Vekua (1996); Medin et al. (2019) \\
\hline Kuruksay & $1.9-1.7$ & Sotnikova (1989) \\
\hline Tegelen & $1.8-1.7$ & Newton (1913); Bernsen (1932); Schreuder (1935, 1949); Erdbrink (1953) \\
\hline Schernfeld & $1.8-1.6$ & Dehm $(1962 a, b)$ \\
\hline Montoussé 5 & $1.8-1.6$ & Clot et al. (1976), Clot and Duranthon (1990) \\
\hline Senéze & $1.8-1.6$ & Schaub (1943); Delson et al. (2006) \\
\hline Trlica & $1.8-1.6$ & Dimitrijević (1990); Dimitrijević et al. (2003); Vislobokova and Agadjanian (2015)) \\
\hline Tsiotra Vryssi & $1.8-1.4$ & Koufos et al. (2018) \\
\hline Marjan & $1.8-1.5 ?$ & Malez $(1959,1961)$ \\
\hline Pietrafitta & $1.7-1.6$ & Rustioni and Mazza (1993a, b) \\
\hline Żabia cave & $1.7-1.5$ & this paper \\
\hline Betfia 13 & $1.6-1.5$ & Terzea (1996) \\
\hline Venta Micena & $1.6-1.5$ & Martínez-Navarro (1991); Torres (1992); Madurell-Malapeira et al. (2015) \\
\hline Valea Graunceanului & $1.6-1.4$ & Radulescu et al. (2003) \\
\hline Barranco León & $1.5-1.4$ & Abbazzi (2010); Martínez-Navarro et al. (2010); Medin et al. (2017) \\
\hline Ubeidiya & $1.5-1.4$ & Ballesio (1986); Martínez-Navarro et al. (2009) \\
\hline Blassac-la-Girondie & $1.5-1.3$ & Heintz et al. (1974) \\
\hline Monte Argentario & $1.5-1.3$ & Petrucci and Sardela (2009) \\
\hline Pirro Nord & $1.5-1.3$ & Petrucci et al. (2013) \\
\hline Fuente Nueva 3 & $1.4-1.3$ & Abbazzi (2010); Medin et al. (2017) \\
\hline Monte Peglia (cf.) & $1.4-1.2$ & Basilici et al. (1991) \\
\hline Apollonia 1 (cf.) & $1.3-1.2$ & Koufos and Kostopoulos (1997); Koufos (2018); Koufos et al. (2018) \\
\hline
\end{tabular}

2007 (2.2-2.0 Ma, found in Saint-Vallier and La Puebla de Valverde), characterized by relatively small teeth, M2 with a narrow talon, $\mathrm{m} 1$ with a bicuspid metaconid, and $\mathrm{m} 2$ with a short talonid; (2) U. e. etruscus Cuvier, 1823 (1.8-1.3 Ma, found in Olivola and Pietrafita), distinguished by smaller anterior premolars and posterior molars larger than those in $U$. e. saintvallierensis, $\mathrm{M} 2$ with a comparatively large talon, $\mathrm{m} 1$ with a bicuspid metaconid, and $\mathrm{m} 2$ with a long talonid; (3) U. e. verescagini Sharapov, 1986 (2.0-1.7 Ma, found in Kuruksai), characterized by the presence of large teeth, comparatively broad $\mathrm{M} 1$ and M2, $\mathrm{m} 1$ with a monocuspid or bicuspid metaconid, and m2 with a moderately long talonid; and (4) U. e. vekuai Baryshnikov, 2007 (1.9-1.7 Ma, Dmanisi) with teeth larger than in other subspecies, with particularly enlarged M2, and $\mathrm{m} 1$ with a bicuspid metaconid (Baryshnikov, 2007; Medin et al., 2019).

According to Medin et al. (2019) the morphometric and morphological variability displayed by the specimens from different localities in Europe is not sufficient to separate them into different subspecies and the known variability can be attributed to sexual dimorphism. Authors however, in general terms, agree with Baryshnikov (2007) in distinguishing two main chronosubspecies, $U$. e. saintvallierensis and $U$. e. etruscus, with the latter as an autochthonous descendent of the former form.

As for the evolutionary relationships of $U$. etruscus, there are two main conceptions. According to Mazza and Rustioni (1992, 1994), and later Wagner (2010), this bear was a highly specialized species without descendants. By contrast, most authors have regarded $U$. etruscus as an ancestor of arctoid and spelaeoid bears (Madurell-Malapeira et al., 2015; Medin et al., 2017,2019 ). The main problem is that among the latest records of $U$. etruscus, from which the species was listed (sometimes tentatively), only a few localities have yielded abundant material. The taxonomic identity of these specimens is not an easy task and some of them may represent early arctoid forms (Wagner, 2010) or were even recently re-described as other bear species, e.g. those from Šandalja 1 (Wagner et al., 2017). In this context, the latest occurrences of $U$. etruscus, dated between 1.3 and 1.2 Ma: e.g. Monte Peglia (Basilici et al., 1991), 
or Colle Curti (Mazza and Rustioni, 1992), should have been cited as Ursus sp. and need further analysis. Only the material from Pirro Nord was revisited and can be classified as $U$. etruscus (Petrucci et al., 2013).

The newly described material of $U$. etruscus from the Jasna Strzegowska cave, although well-preserved, is scanty and could not provide more detailed biostratigraphic information. In view of the accompanying contemporary fauna, an exact age for the finds cannot be given. It can be only tentatively estimated as the Early Pleistocene, between 1.8 and $1.3 \mathrm{Ma}$, which is the time span of occurrence of $U$. etruscus in Europe. Besides the Jasna Strzegowska cave, and the record from Zadębce, the only undisputed Polish record of this species came from the Żabia cave dated at 1.7-1.5 Ma (Nadachowski et al., 2011), where a few isolated teeth and postcranial elements were found.

Similarly to the find of $U$. etruscus from the Jasna Strzegowska cave, the material of $U$. deningeri from this site was also re-deposited and lacks detailed stratigraphic context. According to molecular data, divergence between the arctoid and spelaeoid bear lineages occurred at $\sim 2.75 \mathrm{Ma}$ (Krause et al., 2008). However, the phylogenetic signal of deep divergence is rather indistinct in the direct fossil record and the first record of phenotypically distinct individuals of the respective lineages are much younger (Wagner and Čermák, 2012). The oldest representatives of both lineages are known since $\sim 1.4-1.2 \mathrm{Ma}$, with the oldest records from Deutsch Altenburg (Rabeder et al., 2010; Wagner, 2010; Wagner and Čermák, 2012). Analysis of the material from the Jasna Strzegowska cave shows a high similarity to the early Middle Pleistocene forms, and a similar age may be supposed for the attribution of the bones to $U$. deningeri.

\section{CONCLUSIONS}

Available bear remains represented by dental and postcranial material from the Jasna Strzegowska cave (southern Poland) have been revised and its taxonomical status was re-evaluated. As a result of this analysis, the presence of two bear species has been documented. The specimens previously assigned to Ursus spelaeus or $U$. sp. were re-determined and assigned to $U$. etruscus and $U$. deningeri. Because the co-existence of both bears is improbable, based on the presence of these species and their morphological characteristics, the age of $U$. etruscus is estimated as Early Pleistocene. For $U$. deningeri, an early Middle Pleistocene age is suggested. This is the first description of fossil material of $U$. etruscus from Poland.

Acknowledgements. We are gratefully acknowledge the helpful comments and suggestions of G.F. Baryshnikov and M. Wolsan and O. Kovalchuk for linguistic improvement. This work was supported by the National Science Centre of Poland, in a grant to Adrian Marciszak entitled "The history of the brown bear Ursus arctos Linnaeus, 1758 evolution in Central Europe as a key to modern species conservation" no. UMO-2015/17/D/ST10/01907. The research was also supported by the Ministry of Science and Higher Education, Poland (project 1076/S/IBŚ/2017) and internal grant for young scientists by the Faculty of Biological Sciences (project no. 0411/2093/18).

\section{REFERENCES}

Abbazzi, L., 2010. La fauna de Cérvidos de Barranco León y Fuente Nueva 3. In: Ocupaciones Humanas en el Pleistoceno Inferior y Medio de la Cuenca de Guadix-Baza, Memoria Científica (eds. I. Toro, B. Martínez-Navarro and J. Agustí): 273-290. Junta de Andalucía, Consejería de Cultura. E.P.G. Arqueología Monográfico.

Argant, A., 1991. Carnivores quaternaries de Bourgogne. Documents des Laboratoires de Geologie de la Faculte des Sciences de Lyon, 115: 1-301.

Argant, A., 2004. Les Carnivores du gisement Pliocène final de Saint-Vallier (Drôme, France). Geobios, 37: 133-182.

Argant, A., 2010. Carnivores (Canidae, Felidae et Ursidae) de Romain-la-Roche (Doubs, France). Revue de Paléobiologie de Genève, 29: 495-601.

Athen, K., 2007. Biometrische Untersuchungen des Stylopodiums, Zygopodiums und Metapodiums pleistozäner Ursiden im Hinblick auf die Evolution des Höhlenbären und die Klassifizierung des Fundmaterials Einhornhöhle/Harz. Ph.D. thesis, Eberhard-Karls-Universität, Tübingen.

Ballesio, R., 1986. Les carnivores du gisement pléistocène d'Oubeidiyeh (Israel). Mémoires et travaux du Centre de recherche français de Jérusalem, 5: 63-91.

Baryshnikov, G., 2006. Morphometrical variability of cheek teeth in cave bears. Scientific Annals, School of Geology, Aristotle University of Thessaloniki, 98: 81-102.

Baryshnikov, G.F., 2007. Semya medvedey (Carnivora, Ursidae) (in Russian). Nauka, Sankt-Petersburg.
Baryshnikov, G., Foronova I., 2001. Pleistocene small cave bear (Ursus rossicus) from the South Siberia, Russia. Cadernos Laboratorio Xeolóxico de Laxe, 26: 373-398.

Baryshnikov, G., Kalmykov, N., 2005. Middle Pleistocene Cave Bear (Ursus deningeri von Reichenau) from Transbaikalia (Russia). Mitteilungen der Kommission für Quartärforschung der Österreichischen Akademie der Wissenschaften, 14: 13-16.

Basilici, G., Faraone, A.G., Gentili, S., 1991. Un nuovo reperto di Macaca nelle brecce ossifere pleistoceniche di Monte Peglia (Terni, Italia centrale). Bolletino della Società Paleontologica Italiana, 30: 251-254.

Bernsen, J.J.A., 1932. Eine Revision der Fossilen Säugetierfauna aus den Tonen van Tegelen. (VI \& VII) Ursus etruscus \& Mustela sp. Natuurhistorisch Maandblad, 21: 20-26.

Berzi, A., 1966. L'orso di Gaville nel Valdarno Superiore. Palaeontographia Italica, 60: 19-32.

Bishop, M.J., 1982. The mammal fauna of the early Middle Pleistocene cavern infill site of Westbury-sub-Mendip, Somerset. Special Papers in Paleontology, 28: 1-107.

Bocheński, Z., Bocheński, Z.M., Tomek, T., 2012. A history of Polish birds. Institute of Systematics and Evolution of Animals, Polish Academy of Sciences, Kraków.

Boeuf, O., 1997. À propos de Chilhac, Senèze, Blassac-la-Girondie (Haute-Loire, France), gisements du Pliocène terminal, leur intéręt biochronologique. In: Actes du Congrès BiochroM'97 (eds. J.-P. Aguilar, S. Legendre and J. Michaux): 661-668. Mémoire et Travaux EPHE, Institut de Montpellier-2. 
Boivin, P., Barbet, P., Boeuf, O., Devouard, B., Besson, J.-C. Hénot, J.-M., Devidal, J.-L., Constantin, C., Charles, L., 2010. Geological setting of the lower Pleistocene fossil deposits of Chilhac (Haute-Loire, France). Quaternary International 223-224: 107-115.

Clot, A., Duranthon, F., 1990. Les mammiferes fossiles du Quaternaire dans les Pyrénées. Accord, Toulouse.

Clot, A., Chaline, J., Heintz, E., Jammot, D., Mourer-Chanviré, C., Rage, J.C., 1976. Montoussé 5 (Hautes-Pyrénées), un nouveau remplissage de fissure à faune de Vertébrés du Pléistocène inférieur. Geobios, 9: 511-514.

Dehm, R., 1962a. Altpleistozäne Säuger von Schernfeld bei Eichstätt in Bayern. Mitteilungen der Bayerischen Staatssammlung für Paläontologie und Historische Geologie, 2: 17-61.

Dehm, R., 1962b. Eine weitere altpleistozäne Spaltenfüllung bei Eichstätt in Bayern. Mitteilungen der Bayerischen Staatssammlung für Paläontologie und Historische Geologie, 2: 63-64.

Delson, E., Faure, M., Guérin, C., Aprile, L., Argant, J., Blackwell, B.A.B., Debard, E., Hancourt-Smith, W., Martin-Suarez, E., Monguillon, A., Parenti, F., Pastre, J.F., Sev, S., Skinner, A.R., Swisher, C.C., Valli, A.M.F., 2006 Franco-American renewed research at the Late Villafranchian locality of Senèze (Haute-Loire, France). Courier Forschunginstitut Senckenberg, 256: 275-290.

Dimitrijević, V., 1990. Prvi rezultati istrazivanja sisarske faune iz Trlice kod Pljevlja (in Croatian). In: Zbornik radova 12. kongresa geologa Jugoslavije, knj. 1: Stratigrafija, sedimentologija, paleontologija, 328-336. Ohrid.

Dimitrijević, V., Zic, J., Mijović, D., 2003. Pleistocene fauna on Trlica near Pljevlja (Montenegro). ProGEO News, 1: 6-7.

Erdbrink, D.P., 1953. A review of fossil and recent bears of the Old World; with remarks on their phylogeny, based upon their dentition. Jan de Lange, Deventer.

Forsyth Major, C.J., 1887. Considerazioni sulle faune dei mammiferi pliocenici e post-pliocenici della Toscana Palaeontographica, 1: 1-82

Forsyth Major, C.J., 1890. Note on a Pliocene mammalian fauna at Olivola in the Upper Val di Magra (Prov. Massa-Carrara), Italy Geological Magazine, 3: 305-308.

Freudenberg, W., 1914. Die Säugetiere des älteren Quartärs von Mitteleuropa mit besonderer Berücksichtigung der Fauna von Hundsheim und Deutschaltenburg in Niederösterreich etc. Geologische und Paläontologische Abhandlungen, Neue Folge, 12: 1-219.

García, N.G., 2003. Osos y otros carnívoros de la Sierra de Atapuerca. Fundación Oso de Asturias, Oviedo.

García, N., Arsuaga, J.L., 2001. Ursus dolinensis: a new species of Early Pleistocene ursid from Trinchera Dolina, Atapuerca (Spain). Comptes Rendus de l'Académie des Sciences. Série II, Sciences de la Terre et des Planètes, 332: 717-725.

Gautier, F., Heintz, E., 1974. Le gisement villafranchien de La Puebla de Valverde (Province de Teruel, Espagne). Bulletin Muséum nationale d'Histoire naturelle 3a série, 228: 113-133.

Gibbard, P., Cohen, K.M., 2008. Global chronostratigraphical correlation table for the last 2.7 million years. Episodes, 31: 243-247.

Gibbard, P., Head, M.J., 2009a. The definition of the Quaternary system/period and the Pleistocene series/epoch. Quaternaire, 20: $125-133$

Gibbard, P., Head, M.J., 2009b. IUGS ratification of the Quaternary System/Period and the Pleistocene Series/Epoch with a base at 2.58 MA. Quaternaire, 20: 411-412.

Hilpert, B., 2006. Die Ursiden aus Hunas - Revision und Neubearbeitung der Bärenfunde aus der Steinberg-Höhlenruine bei Hunas (Gde. Pommelsbrunn, Mittelfranken, Bayern) Friedrich-Alexander-Universität Erlangen-Nürnberg, Erlangen.

ICZN, 1999. International code of zoological nomenclature. International Trust for Zoological Nomenclature, London.

Jánossy, D., 1986. Pleistocene vertebrae faunas of Hungary. Akadémiai Kiadó, Budapest.
Kahlke, R.-D., Garcia, N., Kostopoulos, D.S., Lacombat, F., Lister, A.M., Mazza, P.P.A., Spassov, N., Titov, V.V., 2011. Western Palaearctic palaeoenvironment conditions during communities, and implications for hominin dispersal in Europe. Quaternary Science Reviews, 30: 1368-1395.

Koufos, G.D., 2018. New material and revision of the Carnivora, Mammalia from the Lower Pleistocene locality Apollonia 1, Greece. Quaternary, 1: 1-38.

Koufos, G.D., Kostopoulos, D.S., 1997. New carnivore material from the Plio-Pleistocene of Macedonia (Greece) with the description of a new canid. Münchner Geowissenschaften, 34: 33-63.

Koufos, G.D., Kostopoulos, D.S., 2016. The Plio-Pleistocene large mammal record of Greece: implications for early human dispersals into European. In: Human Evolution in the Southern Balkans (eds. K. Harvati and M. Roksandic): 269-280. Springer, Dordrecht.

Koufos, G.D., Konidaris, G.E., Harvati, K., 2018. Revisiting Ursus etruscus (Carnivora, Mammalia) from the Early Pleistocene of Greece with description of new material. 2018. Quaternary International, 497: 222-239.

Kowalski, K., 1951. Jaskinie Polski, 1 (in Polish). Państwowe Muzeum Archeologiczne, Warszawa.

Kowalski, K., 1959. Katalog ssaków plejstocenu Polski (in Polish). Państwowe Wydawnictwo Naukowe, Warszawa.

Krause, J., Unger, T., Nocon, A., Malaspinas, A.-S., Kolokotronis, S.-O., Stiller, M., Soibelzon, L., Springgs, H., Dear, P.H., Briggs, A.W., Bray, S.C.E., O’Brien, S.J., Rabeder, G., Matheus, P., Cooper, A., Slatkin, M., Pääbo, S., Hofreiter, M., 2008. Mitochondrial genomes reveal an explosive radiation of extinct and extant bears near the Miocene-Pliocene boundary. BMC Evolutionary Biology, 8: 220 .

Kurtén, B., 1956. The bears and hyenas of the interglacials. Quaternaria, 4: 1-13.

Kurtén, B., 1959. On the bears of the Holsteinian Interglacial. Stockholm Contributions in Geology, 2: 73-102.

Kurtén, B., 1969. Die Carnivoren-Reste aus dem Kiesen von Süßenborn bei Weimar. Paläontologische Abhandlungen, Abteilung A - Paläozoologie, 3: 735-756.

Kurtén, B., Crusafon-Pairó, M., 1977. Villafranchian Carnivores (Mammalia) from La Puebla de Valverde (Teruel,Spain). Commentationes Biologicae, 85: 1-39.

Kurtén, B., Poulianos, A.N., 1977. New stratigraphic and faunal material from Petralona Cave with special reference to the Carnivora. Anthropos, 4: 47-130.

Lewis, M., Pacher, M., Turner, A., 2010. The larger Carnivora of the West Runton Freshwater Bed. Quaternary International, 228 116-135.

Madurell-Malapeira, J., Alba, D. M., Moyà-Solà, S., 2009 Carnivora from the late Early Pleistocene of Cal Guardiola (Terrassa, Vallès-Penedès Basin, Catalonia, Spain). Journal of Paleontology, 83: 969-974.

Madurell-Malapeira, J., Morales, J., Vinuesa, V., Boscaini, A., 2015. Úrsidos, hiénidos y félidos del Pleistoceno inferior de Cueva Victoria (Cartagena, Murcia). Mastia, 11-13: 401-432.

Malez, M., 1959. A new old-Pleistocene fauna in Dalmatia. Bulletin Scientifique, 5: 13-14.

Malez, M., 1961. Staropleistocenska fauna koštane breče poluotoka Marjana kod Splita (in Croatian). Palaeontologia Jugoslavica, 4: 1-43.

Martínez-Navarro, B., 1991. Revisión sistemática y estudio cuantitativo de la fauna de macromamíferos del yacimiento de Venta Micena (Orce, Granada). Ph.D. dissertation, Universidad Autónoma de Barcelona, Barcelona

Martinez-Navarro, B., Belmaker, M., Yosef-Bar, O., 2009. The large carnivores from Ubeidiya (early Pleistocene, Israel): biochronological and biogeographical implications. Journal of Human Evolution, 56: 514-524.

Martínez-Navarro, B., Palmqvist, P., Madurell, J., Ros-Montoya, S., Espigares, M.P., Torregrosa, V., Pérez-Claros, J.A., 2010. La fauna de grandes mamíferos de Fuente Nueva 3 y Barranco 
León 5. Estado de la cuestión. In: Ocupaciones Humanas en el Pleistoceno Inferior y Medio de la Cuenc de Guadix-Baza, Memoria Científica (eds. I. Toro, B. Martínez-Navarro and J. Agustí): 197-236. Arqueología Monográfico, Andalucía.

Mazza, P., Rustioni, M., 1992. Morphometric revision of the Eurasian species Ursus etruscus Cuvier. Palaeontographia Italica, 79: 101-146.

Mazza, P., Rustioni, M., 1994. On the phylogeny of Eurasian bears. Palaeontographica A, 230: 1-38.

Medin, T., Martínez-Navarro, B., Rivals, F., Madurell-Malapeira, J., Ros-Montoya, S., Espigares, M.P., Figueirido, B., Rook, L., Palmqvist, P., 2017. Late Villafranchian Ursus etruscus and other large carnivorans from the Orce sites (Guadix-Baza basin, Andalusia, southern Spain): taxonomy, biochronology, paleobiology, and ecogeographical context. Quaternary International, 431: 20-41.

Medin, T., Martínez-Navarro, B., Madurell-Malapeira, J., Figueirido, B., Kopaliani, G., Rivals, F., Kiladze, G., Palmqvist, P., Lordkipanidze, D., 2019. The bears from Dmanisi and the first dispersal of early Homo out of Africa. Scientific Reports, 9: 17752.

Mirosław-Grabowska, J., Cyrek, K., 2009. Archaeology and stratigraphy of the Jasna Strzegowska Cave. Studies of the Faculty of Earth Sciences, University of Silesia, 56: 273-282.

Moullé, P.-E., 1992. Les grands mammifères du Pleistocène inferieur de la grotte du Vallonnet (Roquebrune-Cap-Martin, Alpes-Maritimes). Etude paléontologique des Carnivores, Equidé, Suidé et Bovidés. Ph.D. dissertation, Museum National d'Histoire Naturelle à l'Institut de Paléontologie Humaine, Paris.

Musil, R., 1972. Die Bären der Stranska Skala. Anthropos, 20 107-112.

Musil, R., 1974. Lažánky bei Tišnov - eine neue Fundstätte der Biharfauna. Acta Musei Moraviae, Scientiae naturales, 59: 87-93.

Musil, R., 1995. Large fauna of talus cones at the Stránská Skála Hill. Anthropos Neue Serie, 26: 65-83.

Musil, R., 2001. Die Ursiden-Reste aus der Unterpleistozän von Untermassfeld. Monographien des Römisch-Germanischen Zentralsmuseums, 40: 633-658.

Nadachowski, A., Stefaniak, K., Szynkiewicz, A., Marciszak, A., Socha, P., Schick, P., August, P., 2011. Biostratigraphic importance of the Early Pleistocene fauna from Żabia Cave (Poland) in Central Europe. Quaternary International, 248: 204-218.

Nadachowski, A., Lipecki, G., Ratajczak, U., Stefaniak, K., Wojtal, P., 2016. Dispersal events of the saiga antelope (Saiga tatarica) in Central Europe in response to the climatic fluctuations in MIS 2 and the early part of MIS 1. Quaternary International, 420: 357-362.

Newton, E.T., 1913. On the remains of Ursus etruscus $(=U$. arvernensis) from the Pliocene deposits of Tegelen sur Meuse. Verhandelingen van het Geologisch Mijnbouwkundig Genootschap voor Nederland en Koloniën, Geologische Serie, 1: 249-254.

Petrucci, M., Sardella, R., 2009. Ursus etruscus Cuvier, 1823 from the Early Pleistocene of Monte Argentario (Southern Tuscany, Central Italy). Bollettino della Societŕ Paleontologica Italiana, 48: 89-94.

Petrucci, M., Cipullo, A., Martínez-Navarro, B., Rook, L., Sardella, R., 2013. The late Villafranchian (Early Pleistocene) carnivores (Carnivora, Mammalia) from Pirro Nord (Italy). Palaeontographica Abteilung A Paläozoologie, Stratigraphie, 298: 113-145.

Prószyński, M., 1952. Geological observations of the Bug River Basin (in Polish with English summary). Biuletyn Państwowego Instytutu Geologicznego, 65: 313-340.

Przesmycki, P., 1912. Jaskinie na Wyżynie Małopolskiej (in Polish). Ziemia, 3: 443-444.

Rabeder, G., 1999. Die Evolution des Höhlenbären-Gebisses Mitteilung der Kommission für Quartärforschung der Österreichischen Akademie der Wissenschaften, 11: 1-102.

Rabeder, G., Pacher, M., Withalm, G., 2010. Early Pleistocene bear remains from Deutsch-Altenburg (Lower Austria).
Mitteilungen der Kommission für Quartärforschung der Österreichischen Akademie der Wissenschaften, 17: 1-135.

Radulescu, C., Samson, P.-M., Petculescu, A., Stiucă, E., 2003. Pliocene large mammals of Romania. Coloquios de Paleontología, 1: 549-558.

Ratajczak, U., Shpansky, A.V., Malikov, D.G., Stefaniak, K., Nadachowski, A., Wojtal, P., Ridush, B., Krakhmalnaya, T.V., Stepanchuk, V., Mackiewicz, P., 2016. Quaternary skulls of the saiga antelope from Eastern Europe and Siberia: Saiga borealis versus Saiga tatarica - One species or two? Quaternary International, 420: 329-347.

Rode, K., 1931. Über die Bären von Taubach und Ehringsdorf. Paläontologische Zeitschrift, 13: 61-72.

Rode, K., 1935. Untersuchungen uber das Gebiss der Bären. Monographien zur Geologie und Paläontologie, 2: 1-162.

Rook, L., Croitor, R., Delfino, M., Ferretti, M.P., Gallai, G., Pavia, M., 2013. The Upper Valdarno Plio-Pleistocene vertebrate record: an historical overview, with notes on palaeobiology and stratigraphic significance of some important taxa. Bollettino della Societŕ Paleontologica Italiana, 132: 140-125.

Rustioni, M., Mazza, P., 1993a. The genus Ursus in Eurasia: dispersal events and stratigraphical significance. Rivista Italiana di Paleontologia e Stratigrafia, 98: 487-494.

Rustioni, M., Mazza, P., 1993b. The Late Villafranchian bear from Pietrafitta (Perugia, Central Italy). Palaeontographia Italica, 80: 51-62.

Rybicka, M., Cyrek, K., 1997. Wyniki weryfikacyjnych badań wykopaliskowych w Jaskini Jasnej w Strzegowej, woj. Katowickie, w 1991 roku (in Polish). Łódzkie Sprawozdania Archeologiczne, 3: 5-13.

Sawicki, L., 1949. Rozwój badań w zakresie prehistorii czwartorzędu w Polsce (in Polish). Sprawozdania Państwowego Muzeum Archeologicznego, 2: 13-30.

Sawicki, L., 1953. Stan badań nad wiekiem człowieka kopalnego w Polsce (in Polish). Acta Geologica Polonica, 3: 171-186.

Schaub, S., 1943. Die ober Pliocäne Säugetierfauna von Seneze (Haute Loire) und ihre verbreitungsgeschichtliche Stellung. Eclogae Geologicae Helvetiae, 36: 270-289.

Sher, A.V., Weinstock, B.J., Baryshnikov, G.F., Davydov, S.P., Boeskorov, G.G., Zazhigin, V.S., Nikolskiy, P.A., 2011. The first record of "spelaeoid" bears in Arctic Siberia. Quaternary Science Reviews, 30: 2238-2249.

Sotnikova, M.V., 1989. Khishchnye mlekopitayushchiye pliotsenarannego pleistotsena (stratigraficheskoye znacheniye) (in Russian). Nauka, Moskva.

Stefaniak, K., 2015. Neogene and Quaternary Cervidae from Poland. Institute of Systematics and Evolution of Animals, Polish Academy of Sciences, Kraków.

Stefaniak, K., Socha, P., Tyc, A., Cyrek, K., Nadachowski, A., 2009. Caves, rock shelters and palaeontological sites in quarries of the Czestochowa Upland - catalogue of important speleological features. Studies of the Faculty of Earth Sciences, University of Silesia, 56: 307-354

Symeonidis, N., 1992. Lower Pleistocene (Villafranchian) mammalian fossils from the basin of Sesklon (Volos). Annales Geologiques des Pays Helleniques, 35: 1-41.

Szelerewicz, M., Górny, A., 1986. Jaskinie Wyżyny Krakowsko-Wieluńskiej (in Polish). Polskie Towarzystwo Turystyczno-Krajoznawcze „Kraj”, Warszawa-Kraków.

Tchernov, E., Tsoukala, E., 1997. Middle Pleistocene (Early Toringian) carnivore remains from northern Israel. Quaternary Research, 48: 122-136.

Terzea, E., 1996. Biochronology of the Pleistocene deposits at Betfia (Bihor, Komnnii). Acta Zoologica Cracoviensia, 39 531-540.

Torre, D., Albianelli, A., Azzaroli, A., Ficcarelli, G., Magi, M., Napoleone, G., Sagri, M., 1993. Paleomagnetic calibration of the Late Villafranchian mammalian faunas from the Upper Valdarno, Central Italy. Memorias Societa Geologica Italiana, 49: 335-344.

Torres, T.D., 1988. Osos (Mammalia, Carnivora, Ursidae) del Pleistoceno Ibérico: I. Filogenia; Distribución estratigráfica y 
geográfica. Estudio anatómico y métrico del cráneo. Boletín Geológico y Minero, 99: 3-46.

Torres, T.D., 1992. Los restos de oso del yacimiento de Venta Micena (Orce, Granada) y el material de Ursus etruscus C. Cuvier del Villafranquiense Europeo. In: Proyecto Orce-Cueva Victoria (1988-1992). Presencia humana en el Pleistoceno inferior de Granada y Murcia (ed. J. Gibert): 87-106. Museo de Prehistoria, Orce.

Vekua, A., 1996. Die Wirbeltierfauna des Villafranchium von Dmanisi und Ihre biostratigraphische Bedeutung. Jahrbuch des Römisch-Germanischen Zentralmuseums, 42: 77-180.

Viret, J., 1954. Le loess a bancs durcis de Saint-Vallier (Drome) etsa faune de mammiféres villafranchiens. Nouvelles Archives du Muséum d'Histoire Naturelle de Lyon, 4: 1-200.

Vislobokova, I.A., Agadjanian, A.K., 2015. New data on large mammals of the Pleistocene Trlica fauna, Montenegro, the Central Balkans. Paleontological Journal, 6: 86-102.

von Reichenau, W., 1904. Über eine neue fossile Bären-Art Ursus deningeri aus den fluviatilen Sanden von Mosbach. Jahrbücher des Nassauischen Vereins für Naturkunde, 57: 1-11. von Reichenau, W., 1906. Beiträge zur näheren Kenntnis der Carnivoren aus den Sanden von Mauer und Mosbach. Abhandlunge der Grossherzoglich Hessischen Geologischen Landesanstalt zu Darmstadt, 4: 189-313.

Wagner, J., 2010. Pliocene to early Middle Pleistocene ursine bears in Europe: a taxonomic overview. Journal of the National Museum of Prague, Natural History Series, 179: 197-215.

Wagner, J., Čermák, S., 2012. Revision of the early Middle Pleistocene bears (Ursidae, Mammalia) of Central Europe, with special respect to possible co-occurrence of spelaeoid and arctoid lineages. Bulletin of Geosciences, 87: 461-496.

Wagner, J., Jiangzuo, Q., Lenardić, J.M., Liu, J., 2017. Taxonomic revision of bears from the locality Šandalja I (Croatia) and its biostratigraphic consequences. Fossil Imprint, 73: 533-544.

Wiszniowska, T., 1989. Middle Pleistocene Carnivora (Mammalia) from Kozi Grzbiet in the Świętokrzyskie Mts., Poland. Acta Zoologica Cracoviensia, 32: 589-630.

Wolsan, M., 1989. Drapieżne - Carnivora (in Polish). Folia Quaternaria, 59-60: 177-197. 